\title{
HUBUNGAN POLA MAKAN DAN GAYA HIDUP DENGAN KADAR ASAM URAT PRALANSIA DAN LANSIA DI WILAYAH KERJA PUSKESMAS I KEMBARAN, BANYUMAS, JAWA TENGAH
}

\author{
Mutiara Ridhoputrie ${ }^{1}$, Dewi Karita ${ }^{1}$, M Fadhol Romdhoni ${ }^{1}$, Anis Kusumawati ${ }^{1}$ \\ ${ }^{I}$ Fakultas Kedokteran, Universitas Muhammadiyah Purwokerto \\ Email: mutiararidho09@gmail.com
}

\begin{abstract}
Hyperuricemia is a condition when the blood uric acid level exceeds the normal amount. Uric acid is product from purin metabolism, which is from food such as innards, nuts, spinach, etc. There are many affecting factors of hyperuricemia. To determine relationship between eat pattern and life style with uric acid level on pre-elderly and elderly at Puskesmas I Kembaran. Observational analytic research with cross-sectional study with 64 participant of Prolanis Puskesmas I Kembaran with age $\geq 45$ years old. Bivariate analysis with Chi-square test, and multivariate analysis with multivariate logistic regression test. 64 participants consist of 23 pre-elderly and 41 elderly. There is a unsignificantly relationship between uric acid level with eat pattern $(0,281)$ and life style $(0,448)$ with $p<0,05$. Multivariate analysis $\mathrm{p}=0,393$ for eat pattern and $\mathrm{p}=0,703$ for life style and odds ratio life style greater than eat pattern $(1,918 ; 2,385)$. The factor that affect uric acid level are eat pattern and life style. For examples are high purin consumption, low of activity, and smoke. Unsignifantly relationship between eat pattern and life style with uric acid level on pre-eldely and elderly at Puskesmas I Kembaran.
\end{abstract}

Keywords: Eat pattern, Life Style, Uric acid, Pre-Elderly, Elderly

\begin{abstract}
ABSTRAK
Hiperurisemia merupakan keadaan dengan kadar asam urat dalam darah melebihi normal. Asam urat merupakan hasil akhir metabolisme purin yang didapat dari makanan seperti jeroan, kacang-kacangan, sayur bayam, dan lain-lain. Terdapat beberapa faktor yang memengaruhi hiperurisemia. Untuk mengetahui hubungan antara pola makan dan gaya hidup dengan kadar asam urat pada pralansia dan lansia di wilayah kerja Puskesmas I Kembaran. Penelitian analitik observasional dengan pendekatan cross sectional dengan 64 peserta Prolanis Puskesmas I Kembaran berusia $\geq 45$ tahun. Analisis bivariat dengan chi-square dan analisis multivariat dengan regresi logistik multivariat. 64 responden terdiri dari 23 pralansia dan 41 lansia. Terdapat hubungan yang tidak signifikan antara kadar asam urat terhadap pola makan $(0,281)$ dan gaya hidup $(0,448)$ dengan $p<0,05$. Analisis multivariat $p=0,393$ untuk pola makan dan $p=0,703$ untuk gaya hidup dan odds ratio gaya hidup lebih besar dibanding pola makan $(1,918 ; 2,385)$. Faktor yang dapat memengaruhi kadar asam urat yaitu pola makan dan gaya hidup. Contohnya konsumsi tinggi purin, aktivitas yang kurang, dan merokok. Terdapat hubungan yang tidak signifikan antara pola makan dan gaya hidup dengan kadar asam urat pada pralansia dan lansia di wilayah kerja Puskesmas I Kembaran.
\end{abstract}

Kata Kunci: Pola makan, Gaya hidup, Asam Urat, Pralansia, Lansia.

\section{PENDAHULUAN}

Asam urat merupakan hasil akhir metabolisme dari purin. Sebagian besar purin berasal dari makanan terutama daging jeroan, beberapa jenis sayuran, dan kacang-kacangan. Dalam keadaan normal, asam urat dapat larut di dalam darah pada tingkat tertentu. Apabila kadar asam urat dalam darah melebihi daya larutnya, maka plasma darah akan menjadi sangat jenuh dan keadaan ini disebut dengan hiperurisemia ${ }^{1}$. Salah satu contoh penyakit yang ditandai dengan hiperurisemia adalah penyakit gout atau arthritis gout ${ }^{2}$.

Data The Third National Health and Nutrition Examination Survey (NHANES III) pada tahun 1988 hingga 1994 di Amerika Serikat menunjukkan bahwa 
penyakit gout menyerang lebih dari 3 juta pria dengan usia $\geq 40$ tahun dan 1,7 juta wanita dengan usia $\geq 40$ tahun $^{3}$. Tahun 2007 hingga 2008 terjadi peningkatan menjadi 8,3 juta penderita, dengan jumlah penderita pria berjumlah 6,1 juta penduduk dan penderita wanita berjumlah 2,2 juta penduduk ${ }^{4}$. Penelitian oleh Tjokroprawiro pada tahun 2007 ditemukan prevalensi pada populasi di Amerika Serikat diperkirakan 13,6/100.000 penduduk, sedangkan prevalensi di Indonesia diperkirakan 1,6-13,6/100.000 penduduk, dan angka tersebut meningkat dari tahun ke tahun ${ }^{5}$.

Berdasarkan data Riset Kesehatan Dasar (Riskesdas) pada tahun 2013, kejadian penyakit sendi di Jawa Tengah mencapai $25,5 \%$, yang salah satunya adalah penyakit gout. Diantara prevalensi tersebut, lebih banyak diderita oleh perempuan $(27,5 \%)$ dibandingkan dengan laki-laki (21,8\%). Berdasarkan usia, pada usia 35-44 tahun didapatkan prevalensi $26,9 \%$ dan pada usia $>75$ tahun didapatkan prevalensi 54,8\% ${ }^{6}$.

Peningkatan kadar asam urat yang berlebihan dapat disebabkan oleh dua kemungkinan utama yaitu kelebihan produksi asam urat dalam tubuh atau terhambatnya pembuangan asam urat oleh tubuh. Kelebihan produksi asam urat dapat dipengaruhi oleh jenis makanan yang dikonsumsi, konsumsi alkohol, dan obesitas. Sedangkan pembuangan yang terhambat dapat dipengaruhi oleh obat-obatan seperti diuretik dan penyakit ginjal atau intoksikasi ${ }^{7}$.

Kadar asam urat dalam tubuh dipengaruhi oleh beberapa faktor, contohnya yaitu pola makan dan gaya hidup. Pola makan meliputi frekuensi makan, jenis makanan, dan jumlah makanan ${ }^{8}$. Gaya hidup merupakan pola tingkah laku sehari-sehari yang patut dijalankan oleh suatu kelompok sosial ditengah masyarakat meliputi aktivitas fisik, kebiasaan istirahat, dan kebiasaan merokok ${ }^{9}$.

Hasil survei World Health OrganizationInternational League of Associations for Rheumatology Community Oriented Program for Control of Rheumatic
Disease (WHO-ILAIR Copcord) di Sulawesi Utara dan Manado yaitu terdapat hubungan antara asam urat menahun dengan pola konsumsi dan gaya hidup, diantaranya konsumsi alkohol dan kebiasaan makan makanan yang mengandung tinggi purin ${ }^{10}$. Penelitian terdahulu ditemukan hasil kadar asam urat perokok lebih rendah dibandingkan bukan perokok ${ }^{11}$.

Di Kabupaten Banyumas, beberapa penyakit dengan prevalensi yang cukup tinggi yaitu hipertensi, diabetes melitus, dan sindrom metabolik. Oleh karena itu terdapat Program Pengelolaan Penyakit Kronis (Prolanis) untuk mengelola pasien dengan penyakit kronis. Puskesmas I Kembaran merupakan salah satu puskesmas dengan peserta Prolanis terbanyak dan kegiatannya rutin satu kali dalam satu minggu. Oleh karena itu tujuan dari penelitian ini yaitu untuk mengetahui hubungan antara pola makan dan gaya hidup dengan kadar asam urat pada pralansia dan lansia di wilayah kerja Puskesmas I Kembaran.

\section{METODE}

Penelitian observasional analitik dengan metode studi cross sectional. Populasi penelitian yaitu peserta Prolanis Puskesmas I Kembaran dengan jumlah 179 orang, dengan rumus Slovin didapatkan sampel sebanyak 64 sampel. Kriteria inklusi subjek penelitian adalah peserta Prolanis, berusia $\geq 45$ tahun, dan bersedia mengikuti penelitian.

Data primer yaitu karakteristik subjek, pola makan, gaya hidup yang didapat dengan menggunakan kuesioner dari Romauli (2014), dan data kadar asam urat diukur dengan menggunakan alat ukur asam urat. Data sekunder berupa daftar peserta Prolanis yang didapat dari Puskesmas. Data dilakukan uji normalitas dengan uji Kolomogorov smirnov, analisi bivariat dengan Chisquare test dan analisis multivariat dengan uji regresi logistik multivariat. 


\section{HASIL}

\section{Karakteristik Responden}

Berdasarkan Tabel 1, kelompok pralansia sebanyak 23 orang $(35,9 \%)$ dan lansia sebanyak 41 orang (64,1\%). Pada kedua kelompok, sebagian besar berjenis kelamin perempuan, kelompok pralansia berjumlah 21 orang $(91,3 \%)$ dan kelompok lansia 32 orang (78\%). Kategori pendidikan, baik pada pralansia dan lansia, sebagian besar berpendidikan akhir dasar/menengah yaitu sejumlah $23(100 \%)$ pada pralansia dan $31(75,6 \%)$ pada lansia. Pekerjaan responden sebagian besar pekerjaan lain-lain yaitu tidak bekerja atau sebagai ibu rumah tangga bagi responden perempuan, pada pralansia terdapat 17 $(73,91 \%)$ dan lansia sebanyak $30(73,17 \%)$.

2. Pola Makan, Gaya hidup, dan Kadar Asam Urat Responden

Responden dalam penelitian dibagi menjadi dua kelompok berdasarkan usianya yaitu pralansia dan lansia. Pralansia yaitu seseorang dengan usia 45-59 tahun dan lansia merupakan seseorang dengan usia $>60$ tahun. Jumlah responden dalam kelompok pralansia yaitu 23 responden. Berdasarkan pola makan terdapat 7 responden memiliki pola makan yang baik dengan asam urat normal $(<6 \mathrm{mg} / \mathrm{dl})$ dan 8 respoden memiliki pola makan tidak baik dengan asam urat yang normal ( $>6 \mathrm{mg} / \mathrm{dl}$ ). Pada gaya hidup terdapat 9 responden memiliki gaya hidup baik dengan asam urat normal dan 6 responden memiliki gaya hidup tidak baik dengan asam urat normal.

Pada kelompok lansia terdapat 41 responden. Berdasarkan pola makan terdapat 5 responden memiliki pola makan baik dengan asam urat normal dan 21 responden memiliki pola makan tidak baik dengan asam urat tinggi. Pada gaya hidup terdapat 8 responden dengan gaya hidup tidak baik dengan asam urat tinggi dan 16 responden dengan gaya hidup tidak baik dengan asam urat tinggi.

\section{Analisis bivariat}

Hasil dari uji statistik dengan Chi-square untuk mengetahui hubungan antara pola makan dengan kadar asam urat dan hubungan gaya hidup dengan kadar asam urat disajikan pada Tabel 3. Pada hasil uji statistik pertama, $p$ value antara pola makan dan kadar asam urat yaitu $p=0,281$ yang memiliki arti terdapat hubungan yang tidak signifikan antara kedua variabel tersebut karena nilai $p>0,05$. Uji statistik untuk mengetahui hubungan antara gaya hidup dengan kadar urat didapatkan nilai $p=0,448$ yang memiliki arti terdapat hubungan yang tidak signifikan antara kedua variabel tersebut $(p>$ $0,05)$.

\section{Analisis multivariat}

Hasil uji regresi logistik pada tabel 4.4 didapatkan nilai koefisien pola makan -0,504 dan $p$ value $=0,393$. Hal tersebut menunjukkan bahwa terdapat hubungan negatif dan tidak signifikan antara pola makan dan kadar asam urat pralansia dan lansia di wilayah kerja Puskesmas I Kembaran. Nilai koefisien gaya hidup didapatkan -0,210 dan $p$ value $=0,703$ yang menunjukkan bahwa terdapat hubungan negatif dan tidak signifikan antara gaya hidup dengan kadar asam urat pralansia dan lansia di wilayah kerja Puskesmas I Kembaran. Didapatkan nilai Odds Ratio (OR) gaya hidup $(\mathrm{OR}=1,918)$ lebih besar dibandingkan OR pola makan $(\mathrm{OR}=2,385)$, maka seseorang dengan gaya hidup buruk dapat beresiko 2,385 kali lipat memiliki kadar asam urat yang tinggi. Semakin besar nilai OR maka semakin besar kecenderungan faktor tersebut memunculkan suatu peristiwa ${ }^{12}$. 


\section{DISKUSI}

\section{Hubungan Pola Makan dengan Kadar Asam} Urat

Hasil analisis bivariat mengenai hubungan pola makan dengan kadar asam urat dapat dilihat pada Tabel 4.3. Pada tabel tertulis $p$ value $=0,281$ dengan ketentuan apabila $p>0,05$ maka tidak signifikan, sehingga dapat disimpulkan bahwa terdapat hubungan yang tidak signifikan antara pola makan dengan dengan kadar asam urat pralansia dan lansia di wilayah kerja Puskesmas I Kembaran. Hasil ini sejalan dengan penelitian Yunita et al. (2018) dengan hasil penelitiannya tidak adanya korelasi yang signifikan dan kekuatan korelasinya lemah antar variabel ${ }^{13}$. Pola makan merupakan suatu cara atau usaha dalam pengaturan jumlah dan jenis makanan dengan tujuan mempertahankan kesehatan, status nutrisi, mencegah atau membantu kesembuhan penyakit. Faktor yang memengaruhi pola makan yaitu jumlah makanan, frekuensi makan, dan jenis makanan. Ketiga hal tersebut haruslah seimbang, apabila terdapat satu hal yang melebihi hal yang lainnya maka dapat menyebabkan beberapa keadaan, contohnya adalah obesitas dan dapat berdampak menjadi berbagai macam penyakit ${ }^{8}$.

Penelitian lain yang hasilnya sejalan dengan penelitian ini yaitu penelitian yang dilakukan oleh Purba et al. (2014) mengenai hubungan antara pola makan dan kadar asam urat pada wanita menopause yang menderita gout arthritis. Pada penelitian tersebut menunjukkan hasil tidak terdapat hubungan antara karakteristik subjek penelitian (asupan energi, protein, lemak, karbohidrat, dan purin) dengan kadar asam urat. Akan tetapi, pada penelitian tersebut ditemukan hubungan bermakna antara frekuensi makan sumber purin sedang per minggu dengan kadar asam urat, dengan koefisien relasi spearman rho sebesar 0,692 dan tingkat signifikansi $p=0,000(p$ $<0,05)^{14}$.

Konsumsi makanan tinggi purin memicu tingginya kadar asam urat didalam serum, contoh makanan kaya purin yaitu makanan laut, jeoran, dan kacang-kacangan ${ }^{15}$. Pada penelitian ini menunjukkan bahwa responden yang mengonsumsi makanan kaya purin memiliki kadar asam urat yang tinggi, tetapi kebiasaan tersebut tidak diukur berapa jumlah (gram) dalam sehari dan frekuensi konsumsi dalam satu minggu sudah dispesifikasikan menjadi $\leq 3$ kali atau $\geq 3$ kali dalam satu minggu.

Hasil yang tidak signifikan pada penelitian dapat disebabkan oleh beberapa faktor yaitu karakteristik responden. Responden merupakan peserta Prolanis yang terdaftar sebagai pasien hipertensi dan diabetes melitus di puskesmas, sehingga tidak menutup kemungkinan bahwa responden sedang menjalani terapi dengan beberapa jenis pengobatan. Terdapat beberapa terapi yang dapat memengaruhi kadar asam urat, seperti allupurinol, probenecid, obat anti inflamasi non steroid (OAINS) seperti naproxen dan diklofenak dapat menurunkan kadar asam urat, sedangkan pirazinamid dan rifampicin dapat meningkatkan kadar asam urat ${ }^{13}$.

\section{Hubungan Gaya Hidup dengan Kadar Asam} Urat

Pada tabel 4.3, dinyatakan nilai $p=0,448$ yang memiliki arti terdapat hubungan yang tidak signifikan antara gaya hidup dengan kadar asam urat, karena nilai $p>0,05$. Hal ini sejalan dengan penelitian yang dilakukan Nursilmi (2013) mengenai hubungan pola konsumsi, status gizi, dan aktivitas fisik dengan kadar asam urat lansia ${ }^{16}$. Selain itu, hasil ini diperkuat dengan teori glikolisis. Ketika beraktivitas, tubuh akan berusaha memroduksi energi (ATP) dapat secara aerob 
ataupun anaerob. Pembentukan ATP meliputi glikolisis, siklus krebs, dan transpor eketron. Pada proses glikolisis, glukosa akan diubah menjadi glukosa-6-fosfat dan produk akhirnya adalah asam piruvat yang akan masuk kedalam siklus krebs. Pada keadaan anaerob, contohnya ketika berolahraga atau beraktivitas berat, proses glikolisis terjadi secara anaerob sehinga produk akhirnya adalah asam laktat. Peningkatan asam laktat dalam darah dapat menyebabkan penurunan pengeluaran asam urat oleh ginjal, sehingga aktivitas tidak berpengaruh terhadap kadar asam urat dalam darah ${ }^{17}$.

Gaya hidup yaitu pola tingkah laku sehari-hari yang dijalankan oleh suatu kelompok sosial ditengah masyarakat yang sesuai dengan normadan agamanya (Romauli, 2014). Yang termasuk gaya hidup dalam penelitian ini yaitu aktivitas fisik, kebiasaan istirahat, dan kebiasaan merokok. Penelitian Nursilmi (2013) melaporkan tidak terdapat hubungan yang signifikan antara aktivitas fisik dengan kadar asam urat pada lansia wanita $(p=0,964)$ dan tidak terdapat hubungan pula antara kebiasaan olahraga dengan kadar asam urat $(p=0,433)^{16}$.

Hasil yang tidak signifikan pada penelitian ini disebabkan oleh responden merupakan peserta Prolanis yang terdiagnosis hipertensi dan diabetes melitus. Biasanya pasien hipertensi mengalami kesulitan untuk memulai tidur dan pada pasien diabetes melitus seringkali mengeluhkan sering buang air kecil pada malam hari atau terbangun di malam hari, sehingga kualitas tidur responden tidak baik dan tidar teratur. Penyebab lain yaitu sedikitnya responden yang tidak merokok karena sebagian besar responden merupakan perempuan yang tidak memiliki kebiasaan merokok.

\section{Hubungan Pola Makan dan Gaya Hidup dengan Kadar Asam Urat}

Pada tabel 4.4 nilai koefisien pola makan 0,504 dan $p$ value $=0,393$. Hal tersebut menunjukkan bahwa terdapat hubungan yang negatif yaitu hubungan yang tidak berbanding lurus. Semakin baik pola makan maka semakin menurun kadar asam urat, dan sebaliknya. Hasil $p$ value $=0,393(p<0,05)$ maka hubungannya tidak signifikan. Pada nilai koefisien gaya hidup didapatkan $-0,210$ dan $p$ value $=0,703$ yang menunjukkan bahwa terdapat hubungan negatif dan tidak signifikan antara gaya hidup dengan kadar asam urat pralansia dan lansia di wilayah kerja Puskesmas I Kembaran. Hubungan negatif yang terjadi antara gaya hidup dan asam urat yaitu semakin buruknya gaya hidup maka kadar asam urat menjadi meningkat dan sebaliknya, serta hubungan yang tidak signifikan akibat $p$ value $<$ 0,05 .

Hasil penelitian ini sejalan dengan penelitian Mulyasari (2015) dengan hasilnya terdapat hubungan yang negatif antara asupan kalsium dan vitamin $\mathrm{C}$ terhadap kadar asam urat. Artinya setiap peningkatan asupan protein hewani sebanyak 1 gram/hari akan terjadi peningkatan kadar asam urat darah sebanyak 0,020 gram/dl. Setiap peningkatan asupan vitamin $\mathrm{C}$ dan kalsium sebanyak $1 \mathrm{mg} /$ hari akan menurunkan kadar asam urat darah masingmasing sebanyak 0,005 gram/dl dan 0,001 gram/dl. Beberapa variabel lain yang dapat mempengaruhi kadar asam urat darah antara lain konsumsi alkohol, riwayat penyakit dan aktifitas fisik $^{18}$.

Temuan serupa didapat pada penelitian yang dilakukan pada 40 orang subjek wanita berusia 50 60 tahun di Kecamatan Gajah Mungkur, Semarang yang menunjukkan adanya perbedaan kadar asam urat yang signifikan pada subjek dengan jumlah 
asupan purin yang sama namun memiliki jumlah asupan cairan yang berbeda. Subjek dengan asupan cairan >2000 ml memiliki kadar asam urat yang lebih rendah dibandingkan dengan subjek yang memiliki asupan cairan $<2000 \mathrm{ml}$ setiap harinya ${ }^{19}$.

Hiperurisemia memiliki hubungan dengan beberapa penyakit tertentu seperti displidemia, hipertensi, resistensi insulin dan bahkan penyakit jantung. Peningkatan kadar asam urat banyak terjadi pada kondisi resistensi insulin, dikarenakan hiperinsulinemia dapat menurunkan sekresi asam urat melalui ginjal. Konsentrasi trigliserida yang tinggi dalam darah dapat menyebabkan hiperurisemia melalui sintesis asam lemak dalam hati yang berhubungan dengan sintesis de novo purin yang akan memproduksi asam urat ${ }^{20}$. Asam urat dan hipertensi memiliki hubungan dimana asam urat dapat menghalangi bioavailabilitas dari nitrit oksid yang merupakan vasodilator dan meningkatkan tekanan darah. Hipertensi akan memicu penyakit pembuluh darah dan meningkatkan resistensi pembuluh darah hati yang akan meningkatkan resorbsi asam urat ${ }^{21}$.

\section{Simpulan}

1. Terdapat hubungan yang tidak signifikan antara pola makan dengan kadar asam urat pralansia dan lansia di wilayah kerja Puskesmas I Kembaran.

2. Terdapat hubungan yang tidak signifikan antara gaya hidup dengan kadar asam urat pralansia dan lansia di wilayah kerja Puskesmas I Kembaran.

\section{Ucapan Terimakasih}

Kepada Fakultas Kedokteran Universitas Muhammadiyah Purwokerto yang sudah memberikan dukungan dalam pembuatan artikel dan kepada Puskesmas I Kembaran serta peserta Prolanis Puskesmas I Kembaran yang sudah memberi ijin dan ikut serta dalam penelitian.

\section{Daftar Pustaka}

1. Singh, V., Gomez, V. and Swamy, S. (2010) Approach to a Case of Hyperuricemia, Ind $J$ Aerospace Med. 54(1), pp. 40-6-46.

2. Junaidi, I. (2013) Rematik dan Asam Urat. Jakarta: Bhuana Ilmu Populer.

3. Weaver, AL 2008, Epidemiology of Gout, Cleveland Clinic, Journal of Medicine, Vol. 75, No. 5, pp. S9-S10

4. Zhu, Y., Pandya, B. J. and Choi, H. K. (2011). Prevalence of Gout and Hyperuricemia in the US General Population The National Health and Nutrition Examination Survey 2007 - 2008', American College of Rheumatology, 63(10), pp. 3136-3141.

5. Festy, P., Rosyiatul, A. and Aris, A. (2003) Hubungan Antara Pola Makan dengan Kadar Asam Urat Darah pada Wanita Postmenopause di Posyandu Lansia Wilayah Kerja Puskesmas Dr. Soetomo Surabaya [Skripsi], pp. 1-7.

6. Kemenkes RI, K. K. R. I. (2013) Riset Kesehatan Dasar (RISKESDAS) 2013, Laporan Nasional 2013.

7. Sunkureddi, P., Oghalai, T. U. N. and Karnath, B. M. (2006). Clinical Signs of Gout, Hospital Physician. pp. 39-43.

8. Sediaoetama, A. D. (2006). Ilmu Gizi Jilid I Cetakan Keenam. Jakarta: Dian Rakyat.

9. Romauli. (2014). Pengaruh Gaya Hidup Terhadap Kejadian Hipertensi di RSUD Dr. H. Kumpulan Pane Tebing Tinggi [Skripsi]. Universitas Sumatera Utara.

10. Muniroh, L., Martini, S., Nindya, T.S., and Solfaine R. (2010) Minyak Atsiri Kunyit sebagai Anti Radang pada Penderita Gout Artritis dengan Diet Tinggi Purin [Skripsi], 14(2), pp. 57-64.

11. Meida, N. S. and Sisindra, F. (2005) Kadar Asam Urat Plasma pada Perokok dan Non Perokok, Mutiara Medika, 5(1), pp. 21-26.

12. Nirwana. S.R.A. (2015). Regresi Logistik Multinomial dan Penerapannya dalam Menentukan Faktor yang Berpengaruh pada Pemilihan Program Studi di Jurusan Matematika [Skripsi]. Universitas Negeri Makassar. Makassar.

13. Yunita, E. P., Fitriana, D. I. and Gunawan, A. (2018) Hubungan antara Obesitas, Konsumsi Tinggi Purin, dan Pengobatan terhadap Kadar Asam Urat dengan Penggunaan Allopurinol pada Pasien Hiperurisemia, Indonesian Journal of Clinical Pharmacy, 7(1), pp. 1-9.

14. Purba, R. B., Rumagit, F., and Loleh, N.P. (2014). Pola Makan Dan Kadar Asam Urat pada Wanita Menopause Yang Menderita Gout Arthritis Di Puskesmas Tikala Baru Manado [Skripsi]. Poltekkes Kemenkes Manado.

15. Grahame, H., Simmonds and Carrey (2003). Gout : The At Your Fingertips. London: Class Publishing Gibson RS. 
16. Nursilmi. (2013). Hubungan Pola Konsumsi, Status Gizi, Dan Aktivitas Fisik Dengan Kadar Asam Urat Lansia Wanita Peserta Posbindu Sinarsari Nursilmi [Skripsi]. Institut Pertanian Bogor.

17. Murray, R.K. (2014) Biokimia Harper Edisi 29. Jakarta : EGC

18. Mulyasari, Ade. (2015) Faktor Asupan Zat Gizi Yang Berhubungan Dengan Kadar Asam Urat Darah Wanita Postmenopause [Skripsi]. Universitas Diponegoro.

19. Diantari, E. and Candra, A. (2013) Pengaruh Asupan Purin dan Cairan terhadap Kadar Asam Urat pada Wanita Usia 50-60 Tahun di Kecamatan Gajah Mungkur, Semarang [Skripsi]. Fakultas Kedokteran Universitas Diponegoro.

20. Matsubara, Miyao, Hitoshi Chiba, Shoji Marouka, Shinki Katayose. (2002). Elevated Serum Leptin Concentration in Women with Hyperuricemia, Journal of Atherosclerosis and Thrombosis. pp
9:28-34.

21. Sudoyo, A., Setyohadi, B., Alwi, I., Simadibrata K., Setiati, S. (2012). Buku Ajar Ilmu Penyakit Dalam, Edisi IV. Jakarta: Pusat Penerbitan Ilmu Penyakit Dalam Universitas Indonesia.

\section{Lampiran. TABEL}

Tabel 1. Karakteristik Responden

\begin{tabular}{|c|c|c|c|c|}
\hline \multirow[b]{2}{*}{ Karakteristik } & \multicolumn{2}{|c|}{ Pralansia } & \multicolumn{2}{|c|}{ Lansia } \\
\hline & $\begin{array}{l}\text { Frekuensi } \\
\text { (n) }\end{array}$ & $\begin{array}{c}\text { Persen } \\
\text { (\%) }\end{array}$ & $\begin{array}{l}\text { Frekuensi } \\
\text { (n) }\end{array}$ & $\begin{array}{c}\text { Persen } \\
\text { (\%) }\end{array}$ \\
\hline 1. Usia & 23 & 35,9 & 41 & 64,1 \\
\hline \multicolumn{5}{|l|}{ 2. Jenis Kelamin } \\
\hline a. Laki-laki & 2 & 8,7 & 9 & 22 \\
\hline b. Perempuan & 21 & 91,3 & 32 & 78 \\
\hline Total & 23 & 100 & 41 & 100 \\
\hline \multicolumn{5}{|l|}{ 3. Pendidikan } \\
\hline a. Dasar/menengah & 23 & 100 & 31 & 75,6 \\
\hline b. Perguruan Tinggi & 0 & 0 & 6 & 14,6 \\
\hline c. Lain-lain & 0 & 0 & 4 & 9,8 \\
\hline Total & 23 & 100 & 41 & 100 \\
\hline \multicolumn{5}{|l|}{ 4. Pekerjaan } \\
\hline a. Buruh & 6 & 26,09 & 5 & 12,19 \\
\hline b. Pedagang & 0 & 0 & 2 & 4,88 \\
\hline c. Petani & 0 & 0 & 3 & 7,32 \\
\hline d. PNS & 0 & 0 & 1 & 2,44 \\
\hline e. Lain-lain & 17 & 73,91 & 30 & 73,17 \\
\hline Total & 23 & 100 & 41 & 100 \\
\hline
\end{tabular}


Tabel 2. Pola Makan, Gaya hidup, dan Kadar Asam Urat Responden

\begin{tabular}{ccccccccc}
\hline \multirow{2}{*}{ Asam } & \multicolumn{4}{c}{ Pralansia } & \multicolumn{5}{c}{ Lansia } \\
\cline { 2 - 10 } & \multicolumn{2}{c}{ Pola Makan } & \multicolumn{2}{c}{ Gaya Hidup } & \multicolumn{2}{c}{ Pola Makan } & \multicolumn{2}{c}{ Gaya Hidup } \\
\cline { 2 - 10 } & Baik & Tidak & Baik & Tidak & Baik & Tidak & Baik & Tidak \\
& & Baik & & Baik & & Baik & & Baik \\
\hline Normal & 7 & 8 & 9 & 6 & 5 & 12 & 6 & 11 \\
Tinggi & 5 & 3 & 4 & 4 & 3 & 21 & 8 & 16 \\
\hline Total & 12 & 11 & 13 & 10 & 8 & 33 & 14 & 27 \\
\hline
\end{tabular}

Tabel 3. Analisis Bivariat

\begin{tabular}{lcl}
\hline & Sig. $(p)$ & Keterangan \\
\hline Pola Makan*Asam Urat & 0,228 & Tidak signifikan \\
Gaya Hidup*Asam Urat & 0,448 & Tidak signifikan \\
\hline
\end{tabular}

Tabel 4. Analisis Multivariat

\begin{tabular}{lccccc}
\hline Variabel & Koefisien & df & $p$ value & OR & Keterangan \\
& & & & & \\
\hline Pola Makan & $-0,504$ & 1 & 0,393 & 1,918 & Tidak signifikan \\
Gaya Hidup & $-0,210$ & 1 & 0,703 & 2,385 & Tidak signifikan \\
\hline
\end{tabular}

